Article

\title{
Circulating Renalase as Predictor of Renal and Cardiovascular Outcomes in Pre-Dialysis CKD Patients: A 5-Year Prospective Cohort Study
}

\author{
Ana Cerqueira ${ }^{1,2,3, *,+}$, Janete Quelhas-Santos ${ }^{2,3} \mathbb{D}$, Inês Ferreira ${ }^{1,2,3}$, Susana Sampaio ${ }^{1,2,3}$, Miguel Relvas ${ }^{1}$, \\ Nídia Marques ${ }^{1}$, Cláudia Camila Dias ${ }^{4,5}$ and Manuel Pestana 1,2,3
}

1 Nephrology Department, Centro Hospitalar Universitário São João, 4200-319 Porto, Portugal; inescastroferreira@sapo.pt (I.F.); susana.sampaio@sapo.pt (S.S.); miguel.carvalho@chsj.min-saude.pt (M.R.); nidia.marques@chsj.min-saude.pt (N.M.); mvasconcelos@chsj.min-saude.pt (M.P.)

2 Department of Medicine, Faculty of Medicine, University of Porto, 4200-250 Porto, Portugal; sjanete@med.up.pt

3 Institute for Innovation and Health Research (I3S), Institute of Biomedical Engineering (INEB), Nephrology and Infectious Diseases Research Group, University of Porto, 4200-250 Porto, Portugal

4 Department of Community Medicine Health Information and Decision, Faculty of Medicine, University of Porto, 4200-250 Porto, Portugal; camila@med.up.pt

5 CINTESIS-Center for Health Technology and Services Research, 4200-250 Porto, Portugal

* Correspondence: ana.cerqueira@chsj.min-saude.pt; Tel.: +351-22-5512100; Fax: +351-22-5512228

+ Current Address: Nephrology Department São João Hospital Center, EPE Alameda Prof. Hernâni Monteiro 4200-319, Porto, Portugal.

updates

Citation: Cerqueira, A.; Quelhas-Santos, J.; Ferreira, I.; Sampaio, S.; Relvas, M.; Marques, N.; Dias, C.C.; Pestana, M. Circulating Renalase as Predictor of Renal and Cardiovascular Outcomes in Pre-Dialysis CKD Patients: A 5-Year Prospective Cohort Study. Life 2021, 11, 210. https://doi.org/10.3390/ life11030210

Academic Editor: Emilio Nardi

Received: 7 December 2020

Accepted: 1 March 2021

Published: 8 March 2021

Publisher's Note: MDPI stays neutral with regard to jurisdictional claims in published maps and institutional affiliations.

Copyright: (C) 2021 by the authors Licensee MDPI, Basel, Switzerland. This article is an open access article distributed under the terms and conditions of the Creative Commons Attribution (CC BY) license (https:/ / creativecommons.org/licenses/by/ $4.0 /)$.

\begin{abstract}
Chronic kidney disease (CKD) is an independent risk factor for adverse cardiovascular and cerebrovascular events (MACCEs), and mortality since the earlier stages. Therefore, it is critical to identify the link between CKD and cardiovascular risk (CVR) through early and reliable biomarkers. Acknowledging that CKD and CKD progression are associated with increased sympathetic tone, which is implicated in CVR, and that renalase metabolizes catecholamines, we aimed to evaluate the relationship between renalase serum levels (RNLS) and cardiovascular and renal outcomes. The study included 40 pre-dialysis CKD patients (19F:21M) with median age of 61 (IQ 45-66) years. At baseline, we measured RNLS as well as routine biomarkers of renal and cardiovascular risk. A prospective analysis was performed to determine whether RNLS are associated with CKD progression, MACCEs, hospitalizations and all-cause mortality. At baseline, the median level of RNLS and median estimated glomerular filtration rate (eGFR) were 63.5 (IQ 48.4-82.7) $\mu \mathrm{g} / \mathrm{mL}$ and 47 (IQ 13-119) $\mathrm{mL} / \mathrm{min} / 1.73 \mathrm{~m}^{2}$, respectively. In univariate analysis, RNLS were strongly associated with eGFR, age and Charlson Index. Over the course of a mean follow-up of 65 (47 to 70 ) months, $3(7.5 \%)$ deaths, 2 (5\%) fatal MACCEs, 17 (42.5\%) hospital admissions occurred, and $16(40 \%)$ patients experienced CKD progression. In univariate analysis, RNLS were associated with CKD progression $(p=0.001)$, hospitalizations $(p=0.001)$ and all-cause mortality $(p=0.022)$ but not with MACCEs $(p=0.094)$. In adjusted analysis, RNLS predicted CKD progression and hospitalizations regardless of age, Charlson comorbidity index, cardiovascular disease, hypertension, diabetes and dyslipidemia. Our results suggest that RNLS, closely related with renal function, might have a potential role as predictor of renal outcomes, hospitalizations, and mortality in pre-dialysis CKD patients.
\end{abstract}

Keywords: chronic kidney disease; CKD progression; cardiovascular risk; renalase; MACCEs

\section{Introduction}

Patients with chronic kidney disease (CKD) present markedly increased rates of mortality and cardiovascular disease (CVD) and most of these patients are more likely to die than progress to end-stage renal disease (ESRD) [1,2]. In addition, CKD progression is also associated with increased CVD risk and CV mortality [3], even after adjusting 
for the coexisting multiple traditional and nontraditional risk factors [4-11]. Enhanced sympathetic activity is observed in CKD and it has been clearly shown that it is an important predictor of both mortality and increased risk of CVD [12]. In 2005, during the search to identify proteins secreted by the kidney, that could help explain the high incidence of CVD in patients with CKD and represent new therapeutic targets; a team of researchers by Yale University discovered renalase (RNLS). Renalase is secreted by the kidneys into both the circulatory stream and urine, where it could metabolize catecholamines [12,13]. Levels of RNLS have been reported to be higher in patients with hypertension than healthy individuals [14] and positively associated with blood pressure in clinical studies [15]. In addition, recent studies including non-CKD patients point to a correlation between RNLS and atrial fibrillation, advanced left auricular remodeling [16], coronary artery disease, decreased ejection fraction [14] and to an increased risk of myocardial infarction and stroke [17]. One retrospective study including CKD patients demonstrated an association between RNLS and all-cause mortality and adverse renal outcomes [18].

In the present study, we aimed to analyze, in a cohort study, the association of circulating RNLS with renal function and other biomarkers of CV risk, in pre-dialysis CKD patients and prospectively analyze the role of RNLS as a predictor of cardiovascular and renal risk, assessing its relationship with hard outcomes such as progression of CKD, hospitalizations, major adverse cardiovascular/cerebrovascular events (MACCEs) and mortality.

\section{Methods}

The study population included a cohort of 40 pre-dialysis CKD patients followed-up in the outpatient clinic of the Nephrology Department of São João University Hospital Centre. Patients with acute kidney injury, recent hospital admission $(<2$ weeks), active or recent infections $(<1$ week) and known psychiatric disturbances were excluded from the study.

At baseline, the etiology of the renal disease, CKD stage classification and a validated comorbidity index (Charlson Index) were determined in all recruited patients. Anthropometric measurements, systolic and diastolic blood pressure (mean of 3 measurements) and serum levels of creatinine, urea, phosphate, parathormone, $\mathrm{C}$ reactive protein and proteinuria were evaluated. In addition, blood samples were collected for assessment of RNLS using Uscn Life Science Inc. (Wuhan, China) ELISA kit.

All selected patients were prospectively followed up for a median of 65 (47-70) months, to evaluate hard renal and CV outcomes including progression of CKD and ESRD, hospitalizations, MACCEs as well as CV and all-cause mortality. Data on the occurrence of death, MACCEs [acute coronary syndrome (ACS), heart failure and stroke], hospitalizations and CKD progression were obtained through regular follow-up, complemented by electronic medical records. Renal outcomes included CKD progression, defined as serum creatinine doubling or a $>50 \%$ decrease in eGFR according to CKD-EPI formula, and renal replacement therapy initiation (ESRD) after enrolment.

\section{Statistical Analysis}

Continuous variables were described as minimum, percentile 25, median, percentile 75 and maximum deviations, and categorical variables were presented as absolute $(n)$ and relative frequencies (\%). Differences in continuous variables were assessed by MannWhitney $U$ test, while Chi-square tests were used to analyze differences in categorical variables. A correlation analysis was performed using Spearman correlation coefficients. Logistic regression models were used to visualize the relationships between RNLS and CKD progression and hospitalizations. A $p<0.05$ was considered statistically significant.

\section{Ethics}

The research was approved by the Ethics Committee for Health and the Local Institutional Review Board of São João University Hospital Centre (CES 251.14) and was carried out in accordance with the Declaration of Helsinki (2008) of the World Medical Association. 


\section{Results}

A total of 40 pre-dialysis CKD patients (median age of 61 years; IQ 45-66), male/female $(21 / 19)$, were enrolled in the study. The baseline demographic, clinical and analytical characteristics of the recruited patients are summarized in Table 1.

Table 1. Baseline demographic, clinical and analytical characteristics of the study population $(n=40)$.

\begin{tabular}{lcc}
\hline \multicolumn{1}{c}{ Variable } & & \\
\hline Follow-Up (months), median (P25-P75) & 65.4 & $(57.4-68.6)$ \\
Demographic data & & $(52.5)$ \\
Gender (male), $n$ (\%) & 21 & $(45-66)$ \\
Age (years), median (P25-P75) & 61 & $(2-6)$ \\
Charlson Index, median (P25-P75) & 4.5 & $(117-150)$ \\
Clinical data & & $(66-83)$ \\
Systolic blood pressure (mmHg), (P25-P75) & 137 & $(25-30)$ \\
Diastolic blood pressure (mmHg), (P25-P75) & 76 & $(95.0)$ \\
Body mass index (kg/m²), median (P25-P75) & 27.5 & $(48.42-82.69)$ \\
ACEI/ARBs, $n$ (\%) & 38 & \\
Renalase levels (ug/mL), median (P25-P75) & 63.53 & $(15.0)$ \\
CKD related parameters & & $(13-119)$ \\
Diabetic Nephropathy n (\%) & 6 & $(1.02-2.46)$ \\
eGFR CKD-EPI (mL/min/1.3 m2), median (min-max) & 47 & $(44.5-109.0)$ \\
Creatinine (mg/dL), median (P25-P75) & 1.44 & $(4.60-4.90)$ \\
Urea (mg/dL), median (P25-P75) & 73.5 & $(2.90-4.00)$ \\
Calcium (mg/dL), median (P25-P75) & 4.75 & $(45.0-120.0)$ \\
Phosphate (mg/dL), median (P25-P75) & 3.25 & $(11-31)$ \\
Parathormone (pg/mL), median (P25-P75) & 97.0 & $(154.2-966.8)$ \\
25-OH-Vitamin D (ng/mL), median (P25-P75) & 20 & $(11.60-13.75)$ \\
Protein/creatinine ratio (mg/g), median (P25-P75) & 455.5 & $(39.20-43.55)$ \\
Cardiovascular related parameters & & $(155-207)$ \\
Hemoglobin (g/dL), median (P25-P75) & 12.7 & $(41-59)$ \\
Albumin (g/dL), median (P25-P75) & 41.05 & $(95-180)$ \\
Total Cholesterol (mg/dL), median (P25-P75) & 184 & $(5.3-8.7)$ \\
HDL Cholesterol (mg/dL), median (P25-P75) & 49 & $(1.2-5.7)$ \\
Triglycerides (mg/dL), median (P25-P75) & 121 & $(24.0-177.0)$ \\
Uric Acid (mg/dL), median (P25-P75) & 6.4 & 2.2 \\
C reactive protein (mg/L), median (P25-P75) & 66.0 & \\
BNP (pg/mL), median (P25-P75) & &
\end{tabular}

eGFR: estimated glomerular filtration rate; BNP: B-type natriuretic peptide; ACEI-Angiotensin Converting Enzyme Inhibitors ARBsAngiotensin II receptor blockers.

The median eGFR was 47 (13-119) $\mathrm{mL} / \mathrm{min} / 1.73 \mathrm{~m}^{2}$ : seventeen patients were included in stages $1-2$, nine patients in stages $3 a-3 b$ and fourteen patients in stages $4-5$. The most frequent etiology of CKD was diabetic nephropathy (15\%). Body mass index (BMI) was 27.5 (IQ 25-30) kg/m² and median Charlson index was 4.5 (IQ 2.0-6.0).

Mean RNLS were 65.5 (IQ 48.2-82.69) $\mu \mathrm{g} / \mathrm{mL}$. Renalase levels were significantly higher in patients with more advanced CKD stages, and were closely related with eGFR decline (Figure 1). In addition, RNLS were negatively correlated with hemoglobin levels $(\mathrm{r}=-0.360$, $p=0.023)$ and HDL cholesterol $(\mathrm{r}=-0.455, p=0.004)$ and were positively correlated with age $(\mathrm{r}=0.407, p=0.009)$, Charlson Index $(\mathrm{r}=0.704, p<0.001)$, serum urea $(\mathrm{r}=0.818$, $p<0.001)$, serum creatinine $(\mathrm{r}=0.877, p<0.001)$, serum phosphate $(\mathrm{r}=0.590, p<0.001)$, iPTH $(\mathrm{r}=0.694, p<0.001)$, triglycerides $(0.383, p=0.016)$, uric acid $(\mathrm{r}=0.565, p<0.001)$ and BNP $(\mathrm{r}=0.546 . p=0.003)$ (Table 2). Baseline cardiovascular risk factors, including hypertension, diabetes, dyslipidemia or cerebrovascular disease did not significantly associate with RNLS. However, patients with cardiovascular disease had significantly higher RNLS (59.44 vs. $76.64 \mu \mathrm{g} / \mathrm{mL}, p=0.028$ ) (Table 3). 


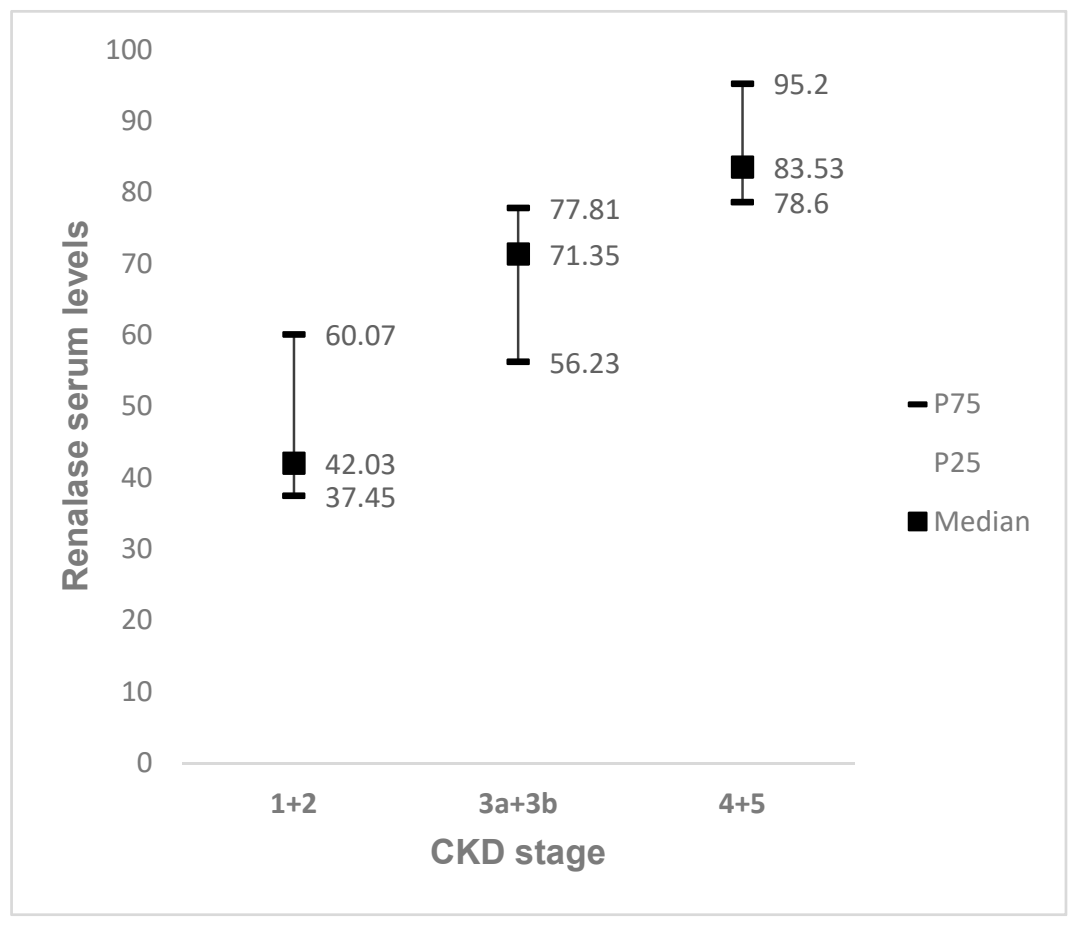

Figure 1. Circulating renalase levels according to increased CKD stages. Significant differences between CKD $4+5$ and CKD $1+2(p<0.05)$.

Table 2. Associations between RNLS and Routine Biomarkers of Renal and Cardiovascular Risk.

\begin{tabular}{lcc}
\hline & \multicolumn{2}{c}{ Renalase } \\
\hline & Spearman Correlation & $p$-Value \\
\hline Demographic data & & \\
Age (years) & 0.407 & $\mathbf{0 . 0 0 9}$ \\
Charlson Index & 0.704 & $<\mathbf{0 0 1}$ \\
CKD related parameters & & \\
eGFR CKD-EPI (mL/min/1.73 m ${ }^{2}$ ) & -0.883 & $<\mathbf{0 . 0 1}$ \\
Creatinine (mg/dL) & 0.877 & $<\mathbf{0 0 1}$ \\
Urea (mg/dL) & 0.818 & $<\mathbf{0 0 1}$ \\
Protein/creatinine ratio (mg/g) & 0.133 & 0.426 \\
Phosphate (mg/dL) & 0.590 & $<\mathbf{0 . 0 0 1}$ \\
Parathormone (pg/mL) & 0.694 & 0.001 \\
25-OH-Vitamin D (ng/mL) & 0.163 & \\
Cardiovascular related parameters & & $\mathbf{0 . 0 2 3}$ \\
Hemoglobin (g/dL) & -0.360 & 0.559 \\
Albumin (g/dL) & -0.095 & 0.480 \\
Total Cholesterol (mg/dL) & -0.236 & $\mathbf{0 . 0 0 4}$ \\
HDL Cholesterol (mg/dL) & -0.455 & $\mathbf{0 . 0 1 6}$ \\
Triglycerides (mg/dL) & 0.383 & $<\mathbf{0 . 0 0 1}$ \\
Uric Acid (mg/dL) & 0.565 & 0.372 \\
C reactive protein (mg/L) & 0.153 & $\mathbf{0 . 0 0 3}$ \\
BNP (pg/mL) & 0.546 &
\end{tabular}


Table 3. Associations between RNLS and patients' comorbidities.

\begin{tabular}{|c|c|c|c|c|c|}
\hline & \multicolumn{5}{|c|}{ Renalase } \\
\hline & P25 & Median & P75 & $n$ & $p$-Value \\
\hline \multicolumn{6}{|c|}{ Hypertension } \\
\hline No & 33.94 & 45.51 & 83.88 & 4 & \multirow[b]{2}{*}{0.279} \\
\hline Yes & 49.18 & 68.17 & 82.69 & 36 & \\
\hline \multicolumn{6}{|c|}{ Diabetes } \\
\hline No & 42.03 & 61.42 & 78.60 & 29 & \multirow[b]{2}{*}{0.209} \\
\hline Yes & 54.06 & 65.63 & 99.54 & 11 & \\
\hline \multicolumn{6}{|c|}{ Dyslipidemia } \\
\hline No & 41.20 & 51.69 & 77.62 & 16 & \multirow[b]{2}{*}{0.104} \\
\hline Yes & 56.23 & 71.35 & 83.74 & 23 & \\
\hline \multicolumn{6}{|c|}{$\begin{array}{l}\text { Cardiovascular } \\
\text { disease }\end{array}$} \\
\hline No & 40.95 & 59.44 & 78.60 & 29 & \multirow{2}{*}{0.028} \\
\hline Yes & 70.71 & 76.64 & 86.61 & 11 & \\
\hline \multicolumn{6}{|c|}{$\begin{array}{l}\text { Cerebrovascular } \\
\text { disease }\end{array}$} \\
\hline No & 47.98 & 60.82 & 83.31 & 38 & \multirow{2}{*}{0.420} \\
\hline Yes & 75.64 & 78.54 & 81.43 & 2 & \\
\hline
\end{tabular}

Over the course of a median follow-up period of 65 (47 to 70) months, 3 patients died, 2 patients suffered a fatal MACCE, 17 patients had at least one hospital admission and 16 patients experienced CKD progression, of which 12 progressed to ESRD and started renal replacement therapy (RRT) (Table 4). Renalase levels were higher at baseline in patients with CKD progression during follow-up (median 80.40 vs. 51.79, $p=0.001$ ), in patients with hospitalizations (median: 81.43 vs. $53.86, p=0.001$ ) and in patients who died (median: 95.20 vs. $60.22, p=0.022$ ) (Table 5). In adjusted analysis, RNLS predicted CKD progression and hospitalizations regardless of age, Charlson comorbidity index, cardiovascular disease, hypertension, diabetes and dyslipidemia (Table 6). The small number of events $(n=3)$ prevented us from performing an adjusted analysis to mortality.

Table 4. Cardiovascular and renal outcomes during follow-up in the studied population.

\begin{tabular}{lc}
\hline Outcome & $\boldsymbol{n} \mathbf{( \% )}$ \\
\hline MACCEs & $2(5.0)$ \\
Acute myocardial infarction & $1(2.5)$ \\
Stroke & $1(2.5)$ \\
Hospital admission for medical causes & $17(42.5)$ \\
Death & $3(7.5)$ \\
Death by MACCEs & $2(5)$ \\
CKD progression & $16(40.0)$ \\
RRT & $12(30.0)$ \\
\hline
\end{tabular}

MACCEs: major adverse cardiovascular and cerebrovascular events; RRT: Renal Replacement Therapy.

Table 5. Association between RNLS and outcomes.

\begin{tabular}{|c|c|c|}
\hline & \multicolumn{2}{|c|}{ Renalase } \\
\hline & Median (P25-P75) & $p$-Value ${ }^{1}$ \\
\hline CKD progression & & 0.001 \\
\hline No & $51.79(40.6-73.5)$ & \\
\hline Yes & $80.4(62.93-88.07)$ & \\
\hline Mortality & & 0.022 \\
\hline No & $60.22(48-78.6)$ & \\
\hline Yes & $95.20(81.4-113.9)$ & \\
\hline
\end{tabular}


Table 5. Cont

\begin{tabular}{|c|c|c|}
\hline & \multicolumn{2}{|c|}{ Renalase } \\
\hline & Median (P25-P75) & $p$-Value ${ }^{1}$ \\
\hline Hospitalization & & 0.001 \\
\hline No & $53.86(40.4-71.4)$ & \\
\hline Yes & $81.43(65.6-95.1)$ & \\
\hline MACCEs & & 0.094 \\
\hline No & $60.82(48-82.1)$ & \\
\hline Yes & $95.12(81.4-108.1)$ & \\
\hline
\end{tabular}

Table 6. Linear regression: association between CKD progression and hospitalizations (dependent variables) and renalase, adjusted to renal function, age, Charlson comorbidity index, cardiovascular disease, hypertension, diabetes and dyslipidemia.

\begin{tabular}{|c|c|c|c|c|c|c|}
\hline & \multicolumn{3}{|c|}{ CKD Progression } & \multicolumn{3}{|c|}{ Hospitalizations } \\
\hline & OR & IC $95 \%$ & $p$ & OR & IC $95 \%$ & $p$ \\
\hline \multicolumn{7}{|l|}{ Model 1} \\
\hline Renalase & 1.055 & $1.015-1.096$ & 0.007 & 1.071 & $1.025-1.119$ & 0.002 \\
\hline $\begin{array}{c}\text { Hosmer Lemeshow } \\
p \text {-value } \\
\text { Model } 2\end{array}$ & & 0.565 & & & 0.797 & \\
\hline Renalase & 1.064 & $1.019-1.112$ & 0.005 & 1.074 & $1.025-1.126$ & 0.003 \\
\hline Age & 0.971 & $0.921-1.023$ & 0.265 & 0.988 & $0.937-1.041$ & 0.645 \\
\hline $\begin{array}{c}\text { Hosmer Lemeshow } \\
p \text {-value } \\
\text { Model } 3\end{array}$ & & 0.095 & & & 0.673 & \\
\hline Renalase & 1.050 & $1.001-1.101$ & 0.044 & 1.062 & $1.008-1.119$ & 0.023 \\
\hline $\begin{array}{l}\text { Charlson comorbidity } \\
\text { index }\end{array}$ & 1.060 & $0.715-1.570$ & 0.773 & 1.117 & $0.740-1.684$ & 0.599 \\
\hline $\begin{array}{c}\text { Hosmer Lemeshow } \\
p \text {-value } \\
\text { Model } 4\end{array}$ & & 0.840 & & & 0.521 & \\
\hline Renalase & 1.068 & $1.021-1.117$ & 0.004 & 1.067 & $1.020-1.116$ & 0.005 \\
\hline Cardiovascular disease & 0.269 & $0.045-1.607$ & 0.150 & 1.518 & $0.287-8.028$ & 0.623 \\
\hline $\begin{array}{c}\text { Hosmer Lemeshow } \\
p \text {-value } \\
\text { Model } 5\end{array}$ & & 0.646 & & & 0.848 & \\
\hline Renalase & 1.054 & $1.015-1.095$ & 0.007 & 1.070 & $1.024-1.117$ & 0.002 \\
\hline Hypertension & 2.261 & $\begin{array}{l}0.084- \\
60.550\end{array}$ & 0.627 & 2.954 & $0.057-153.369$ & 0.591 \\
\hline $\begin{array}{c}\text { Hosmer Lemeshow } \\
p \text {-value } \\
\text { Model } 6\end{array}$ & & 0.477 & & & 0.789 & \\
\hline Renalase & 1.055 & $1.012-1.101$ & 0.012 & 1.074 & $1.023-1.127$ & 0.004 \\
\hline Diabetes & 3.333 & $\begin{array}{l}0.635- \\
17.502\end{array}$ & 0.155 & 3.050 & $0.517-17.984$ & 0.218 \\
\hline $\begin{array}{c}\text { Hosmer Lemeshow } \\
p \text {-value } \\
\text { Model } 7\end{array}$ & & 0.775 & & & 0.775 & \\
\hline Renalase & 1.052 & $1.012-1.095$ & 0.011 & 1.072 & $1.026-1.121$ & 0.002 \\
\hline Dyslipidemia & 2.413 & $\begin{array}{l}0.510- \\
11.423\end{array}$ & 0.267 & 0.797 & $0.157-4.058$ & 0.785 \\
\hline $\begin{array}{l}\text { Hosmer Lemeshow } \\
\quad p \text {-value }\end{array}$ & & 0.561 & & & 0.461 & \\
\hline
\end{tabular}




\section{Discussion}

In the present study, we investigated the association between RNLS and traditional $\mathrm{CV}$ risk factors including eGFR in a cohort of non-dialysis CKD patients. In addition, we examined the role of RNLS as a biomarker of CV and renal outcomes in this pre-dialysis CKD patient population, prospectively followed-up for more than 5 years. Our main findings were the following: (i) RNLS are closely correlated with the decrease in eGFR in pre-dialysis CKD patients; (ii) RNLS are associated with cardiovascular disease in pre-dialysis CKD patients; (iii) Pre-dialysis CKD patients with higher RNLS at baseline presented higher rates of progression of CKD, hospitalizations and mortality, but not MACCEs.

In the present study, we found that RNLS assessed by a commercially available ELISA kit were strongly and inversely associated with eGFR. Our results agree well with the previous observations from our and other groups that reported that RNLS assessed by ELISA assay with specific monoclonal antibody are negatively associated with renal function. In the recent literature, seven studies were carried out in CKD patients stages 1 to 4 , and five of them provided evidence for a negative relationship between RNLS and eGFR (Table 7). The other two studies reporting discrepant results used different commercial ELISA kits to access RNLS, which may justify the different observations (Table 7). Findings similar to ours showing inverse correlation between RNLS and eGFR were also reported in other CKD populations, including kidney transplant recipients [19,20], patients on peritoneal dialysis [21] and patients on hemodialysis [22] (Table 7).

Table 7. Data from the most Relevant and Recent Studies Evaluating Renalase by ELISA in CKD Patients.

\begin{tabular}{|c|c|c|}
\hline & Levels of Circulating Renalase by Elisa Kit & Correlation with Renal and CV Outcomes \\
\hline \multicolumn{3}{|l|}{ CKD Patients Stages 1-4 } \\
\hline $\begin{array}{l}\text { A. Gluba-Brzózka et al. } 2014 \text { [23] } \\
139 \text { CKD patients } \\
45 \text { healthy volunteers }\end{array}$ & $\begin{array}{l}\text { Increased concentrations of renalase } \\
\text { control vs. CKD group } \\
251.0 \pm 157 \text { vs. } 316.1 \pm 155.3 \mathrm{ng} / \mathrm{mL}, p=0.026 \\
\text { USCN Life Science, E } 92845 \mathrm{Hu}\end{array}$ & $\begin{array}{l}\text { Increased concentration of osteocalcin, } \\
\text { renalase, MMP- } 2 \text { and TIMP- } 2 \text { suggest that } \\
\text { these factors may be involved in the } \\
\text { pathogenesis of CAD in patients with CKD. }\end{array}$ \\
\hline $\begin{array}{l}\text { J. Quelhas-Santos et al. } 2014 \text { [20] } \\
26 \text { ESRD patients }\end{array}$ & $\begin{array}{l}\text { Plasma renalase levels }(\mathrm{ug} / \mathrm{mL}) \\
4.7 \pm 0.5 \mathrm{LKD} \\
29.4 \pm 4.0 \mathrm{LKR} \text { before } \mathrm{TX}(p<0.05) \\
\text { USCN Life Science, E92845Hu }\end{array}$ & $\begin{array}{l}\text { Plasma renalase levels closely depend on } \\
\text { renal function and sympathetic nervous } \\
\text { system activity. }\end{array}$ \\
\hline
\end{tabular}

Renalase levels not different between groups

CKD1-2 (162.1 $\pm 40.1 \mathrm{ng} / \mathrm{L})$ vs. healthy

control group $(167.8 \pm 69.4 \mathrm{ng} / \mathrm{L})$

F. Wang et al. 2015 [15]

group CKD3-5 (217.4 $\pm 103.8 \mathrm{ng} / \mathrm{L})$ were

Serum renalase levels were positively

significantly increased compared with group correlated with CKD stage $(p<0.05)$, while

CKD1-2 $(p<0.05)$

ELISA Yaji Biological Corp

negatively correlated with eGFR $(p<0.05)$

S. H. Baek et al. 2019 [18]

383 patients with CKD

38 children with CKD (stage G2-5)

38 healthy children

M. Wiśniewska et al. 2019 [25]

155 white patients with CKD

30 healthy controls
Mean level of serum renalase was $75.8 \pm 34.8$ $\mu \mathrm{g} / \mathrm{mL}$

ELISA Cloud Clone Corp
Higher serum creatinine levels were significantly associated with a higher renalase levels.

Increase in serum renalase was associated with all-cause mortality and adverse renal outcomes, but not associated with the rate of MACCEs.

In multivariate analysis GFR $(\beta=-0.63$, $p<0.001)$, was determinant of renalase In children with CKD there is a strong correlation between renalase level and CKD stage.

compared tovel was higher in the study group ELISA CloudClone Corp

Serum renalase levels were higher in patients with CKD than in controls: median (Q1-Q3), $103 \mathrm{ng} / \mathrm{mL}(55.6-166 \mathrm{ng} / \mathrm{mL})$ vs. $17.7 \mathrm{ng} / \mathrm{mL}$ (16.3-21.8 ng/mL); $p<0.001$ ELISA kit EIAab
No association between serum renalase and eGFR.

No associations were found between renalase concentrations and other causes of CKD. 
Table 7. Cont.

\begin{tabular}{lll}
\hline & Levels of Circulating Renalase by Elisa Kit & Correlation with Renal and CV Outcomes \\
\hline & The concentration of renalase in the serum of & \\
N. M. Serwin et al. 2020 [26] & CKD patients was much higher in comparison & Renalase levels in serum are not related to \\
62 CKD patients stages I to IV & to material from healthy individuals 36.1 & the glomerular filtration rate. \\
28 healthy controls & $(18.3-109.1)$ vs. 11.1 (2.5-26.5) ng/mL & \\
& ELISA kit EIAab
\end{tabular}

\section{HD and DP Patients}

E. Zbroch et al. 2012 [22]

$104 \mathrm{HD}$ patients

E.-Zorawska et al. 2012 [28]

$60 \mathrm{HD}$ patients

E. Zbroch et al. 2012 [21]

26 PD patients

E. Zbroch et al. 2013 [29]

75 HD patients

M. Dziedzic et al. 2014 [30]

49 HD patients

Mean serum renalase in the study cohort was significantly higher than in the control group $(27.53 \pm 7.18$ vs. $3.86 \pm 0.73 \mu \mathrm{g} / \mathrm{mL}, p<0.001)$ USCN Life Science, E92845Hu

Mean serum renalase concentration in the study cohort was $17.516 .73 \mu \mathrm{g} / \mathrm{mL}$ and it was significantly higher when compared with the healthy volunteers-3.99 $1.73 \mu \mathrm{g} / \mathrm{mL}$ $(p<0.001)$

USCN Life Science, E92845Hu

Mean level of renalase was significantly

higher in HD patients when compared to the control group $(27.53 \pm 9.39 \mu \mathrm{g} / \mathrm{mL}$ vs.

$4.00 \pm 1.37 \mu \mathrm{g} / \mathrm{mL}, p<0.001$

USCN Life Science, E92845Hu

Serum concentration of renalase was significantly higher in patients dialyzed for more than 6 months than in those dialyzed for fewer than 6 months $(21.15 \pm 4.58 \mu \mathrm{g} / \mathrm{mL}$ vs. $16.63 \pm 2.86 \mu \mathrm{g} / \mathrm{mL}, p=0.008)$

USCN Life Science, E92845Hu

HD patients had higher renalase levels

$(27.49 \pm 6.9 \mathrm{ug} / \mathrm{mL})$ Renalase were higher in

dialyzed groups $(19.24 \pm 4.5 \mathrm{ug} / \mathrm{mL})$

comparing to healthy volunteers

$(3.86 \pm 0.74 \mathrm{ug} / \mathrm{mL})$

USCN Life Science, E92845Hu

The mean concentration of renalase in the entire study population was $126.59 \pm 32.63$ $\mathrm{ng} / \mathrm{mL}$

USCN Life Science, E92845Hu
Serum renalase levels were significantly higher in HD patients $(212 \pm 127 \mathrm{ng} / \mathrm{mL})$ compared to controls $(116 \pm 67 \mathrm{ng} / \mathrm{mL})$ $(p<0.001)$.

USCN Life Science, E92845Hu
Significant inverse correlation between the serum renalase and residual renal function $(\mathrm{r}=-0.327, p=0.001)$.

Renalase was not related to blood pressure, heart rate or hemodialysis vintage.

Serum renalase correlated with creatinine $(\mathrm{r}=0.43, p<0.05)$, residual renal function $(\mathrm{r}=0.39, p<0.05)$. The only predictor of renalase in multiple regression analysis was the presence of hypertension explaining $90 \%$ of the renalase variations.

Renalase appeared to be unrelated to Vascular adhesion protein-1.

Renalase was not related to BP control, BP level, sex, dialysis adequacy, or residual renal function.

Renalase correlated with dialysis vintage and inversely with residual diuresis. HD population with CAD had higher renalase level than their PD counterparts.

Inverse correlation between NT-proBNP and renalase plasma levels in HD patients were due to impaired kidney function, accompanied by increased sympathetic nerve activity, which have an impact on the development of hypertension and cardiovascular complications.

Renalase was positively correlated with serum creatinine and dialysis vintage $(\mathrm{r}=0.677, p<0.001$ and $\mathrm{r}=0.625, p<0.001$, respectively).

There was no significant association of renalase with LVMI in the HD patients $(\mathrm{r}=0.263, p=0.065)$.

Serum renalase level was significantly higher in the PD patients than in the control group [176.5 (100-278.3) vs. $122(53.3-170.0) \mathrm{ng} / \mathrm{mL}]$ $(p=0.001)$

USCN Life Science, E92845Hu
Renalase was negatively correlated with $\operatorname{RRF}(\mathrm{r}=-0.511, p=0.021)$.

Renalase is associated with residual renal function but not with CVD risk factors in PD patients. 
Table 7. Cont.

\begin{tabular}{|c|c|c|}
\hline & Levels of Circulating Renalase by Elisa Kit & Correlation with Renal and CV Outcomes \\
\hline $\begin{array}{l}\text { M. Wisniewska et al. } 2021 \text { [33] } \\
77 \text { HD patients } \\
30 \text { healthy controls }\end{array}$ & $\begin{array}{l}\text { Renalase serum concentrations in CKD } \\
\text { patients were significantly increased when } \\
\text { compared with control subjects }(185.5 \pm 64.3 \\
\text { vs. } 19.6 \pm 5.0 \mathrm{ng} / \mathrm{mL} ; p<0.00001 \\
\text { ELISA kit EIAab }\end{array}$ & $\begin{array}{l}\text { The decreased plasma concentrations of } \\
\text { catecholamines may be due to their } \\
\text { increased degradation by plasma renalase. }\end{array}$ \\
\hline \multicolumn{3}{|l|}{ Renal Transplant } \\
\hline $\begin{array}{l}\text { J. Malyszko et al. } 2011[19] \\
89 \text { kidney allograft recipients } \\
27 \text { healthy volunteers }\end{array}$ & $\begin{array}{l}\text { The mean serum renalase among recipients } \\
\text { was significantly higher compared with the } \\
\text { control group }(6.72 \pm 4.50 \mu \mathrm{g} / \mathrm{mL} \text { vs. } 3.86 \pm \\
0.73 \mu \mathrm{g} / \mathrm{mL} ; p<0.001) \\
\text { USCN Life Science, E92845Hu }\end{array}$ & $\begin{array}{l}\text { In kidney transplant recipients, renalase } \\
\text { correlated serum creatinine }(\mathrm{r}=0.49 \\
p<0.001) \text { and estimated glomerular } \\
\text { filtration rate } \mathrm{r}=-0.44 ; p<0.0001\end{array}$ \\
\hline $\begin{array}{l}\text { E. Zbroch et al. } 2012 \text { [34] } \\
62 \text { kidney allograft recipients } \\
27 \text { healthy volunteers }\end{array}$ & $\begin{array}{l}\text { The mean serum renalase level in kidney } \\
\text { allograft recipients was significantly higher } \\
\text { compared with the control group }(6.72 \pm 2.86 \\
\mu \mathrm{g} / \mathrm{mL} \text { vs. } 3.86 \pm 0.73 \mu \mathrm{g} / \mathrm{mL}, p<0.001 \\
\text { USCN Life Science, E } 92845 \mathrm{Hu}\end{array}$ & $\begin{array}{l}\text { In hypertensive allograft recipients, renalase } \\
\text { was significantly higher than in } \\
\text { normotensives. A multiple regression } \\
\text { analysis showed that renalase was predicted } \\
\text { in } 58 \% \text { by serum creatinine. }\end{array}$ \\
\hline $\begin{array}{l}\text { D. Stojanovic et al. } 2015 \text { [35] } \\
73 \text { renal TX recipientes }\end{array}$ & $\begin{array}{l}\text { Renalase } \mathrm{ng} / \mathrm{mL} \\
\text { Renal transplant recipients }(141.82 \pm 36.47) \\
\text { Control group }(16.36 \pm 4.13) \\
\text { USCN Life Science, E92845Hu }\end{array}$ & $\begin{array}{l}\text { Significant risk of reduced glomerular } \\
\text { filtration rate in transplant recipients with } \\
\text { increased renalase concentration }(p=0.026) \text {. } \\
\text { Renalase was shown to be strong predictor } \\
\text { of decreased glomerular filtration rate. }\end{array}$ \\
\hline $\begin{array}{l}\text { D. Stojanovic et al. } 2017 \text { [36] } \\
73 \text { renal TX recipients }\end{array}$ & $\begin{array}{l}\text { Plasma renalase level was increased } \\
\text { compared to controls, } 141.82 \mathrm{ng} / \mathrm{mL} \text { vs. } 16.36 \\
\mathrm{ng} / \mathrm{mL}, p<0.0001 \\
\text { USCN Life Science, E92845Hu }\end{array}$ & $\begin{array}{l}\text { Significant inverse correlation between } \\
\text { renalase and estimated glomerular filtration } \\
\text { rate }(\mathrm{r}=-0.552, p<0.001)\end{array}$ \\
\hline
\end{tabular}

Because our study included patients with stages 1 to $5 \mathrm{CKD}$, the strong and inverse association observed between circulating RNLS and renal function reinforces the view that RNLS may represent a useful biomarker for early identification of renal dysfunction in stable pre-dialysis CKD patients.

In our study baseline, CVR factors including hypertension, diabetes, dyslipidemia or cerebrovascular disease did not significantly associate with higher RNLS. There is controversy in the literature regarding the association of hypertension and RNLS. The lack of association between hypertension and RNLS in our study can be explained on the basis that most patients were considered hypertensive because they were on anti-hypertensive medication, although their average blood pressure levels were near normal.

In our pre-dialysis CKD population, patients with cardiovascular disease had significantly higher RNLS. This agrees well with the findings by Gluba-Brzózka et al., that reported higher RNLS in CKD patients with coronary artery disease and further suggested a possible role of RNLS in its pathogenesis.

Our patient population was prospectively followed-up for more than 5 years. During this period, we found that $42.5 \%$ of the patients had at least one hospital admission for medical cause, $40 \%$ suffered a significant decline in eGFR and $30 \%$ progressed to ESRD. Nevertheless, only 3 deaths where registered, of which 2 were from MACCEs. In univariate analysis, positive associations were observed between baseline RNLS and all-cause mortality, hospitalizations, and CKD progression but not with the occurrence of MACCEs. These results are in line with those observed in the retrospective analysis of the data from the K-STAR study including 383 pre-dialysis CKD patients. The authors reported that RNLS were not associated with the occurrence of MACCEsl; nevertheless, they found that each $10 \mu \mathrm{g} / \mathrm{mL}$ increase in RNLS was associated with a significantly greater hazard of all-cause mortality and adverse renal outcomes [18]. In adjusted analysis, RNLS predicted CKD progression and hospitalizations regardless of age, Charlson index, cardiovascular 
disease, diabetes, hypertension or dyslipidemia. It should be emphasized that our results were obtained in a cohort of pre-dialysis CKD patients that were already on renoprotective therapy ( $95 \%$ were on ACEI/ARBs). Taken together, our findings suggest that RNLS can be, not only a biomarker of renal function but, may also provide valuable information in prediction of relevant outcomes in CKD patient population.

We acknowledge some limitations of our study. First, this is a single-center study with a relatively small number of patients and the inherent selection bias; second, we did not enroll healthy subjects as controls for comparing RNLS to those with established CKD; third, the small number of outcomes observed, notwithstanding the 5 years of followup, may have jeopardized the analysis. Nonetheless, to our knowledge, this is the first study to prospectively assess the role of RNLS as predictor of CV and renal outcomes in a pre-dialysis CKD population.

In conclusion, our results show that RNLS are closely related with renal function in pre-dialysis CKD patients. It is also suggested that the role of circulating RNLS may be a useful biomarker to predict renal outcomes, hospitalizations and mortality in pre-dialysis CKD patients. Further studies are needed to explore the possible role of RNLS as a new therapeutic target in the prevention and treatment of CKD and cardiovascular diseases.

Author Contributions: Conceptualization, A.C., J.Q.-S. and M.P.; methodology, A.C., J.Q.-S., I.F. and S.S.; software, A.C., J.Q.-S., and C.C.D.; validation, A.C., J.Q.-S. and C.C.D.; formal analysis, A.C., J.Q.-S. and C.C.D.; investigation, A.C., J.Q.-S., I.F., S.S., M.R., N.M.; C.C.D. and M.P.; resources, A.C., J.Q.-S., I.F., S.S., M.R., N.M.; C.C.D. and M.P.; data curation, A.C., J.Q.-S., I.F., S.S., M.R., N.M. and C.C.D.; writing - original draft preparation, A.C., J.Q.-S., C.C.D. and M.P.; writing—review and editing, A.C., J.Q.-S. and M.P.; visualization, A.C., J.Q.-S., I.F., S.S., M.R., N.M.; C.C.D. and M.P.; supervision, M.P. and J.Q.-S.; project administration, J.Q.-S. and M.P.; funding acquisition, M.P., J.Q.-S. and A.C. All authors have read and agreed to the published version of the manuscript.

Funding: This work was financed by FEDER-Fundo Europeu de Desenvolvimento Regional funds through the COMPETE 2020-Operacional Programme for Competitiveness and Internationalisation (POCI), Portugal 2020, and by Portuguese funds through FCT-Fundação para a Ciência e a Tecnologia/Ministério da Ciência, Tecnologia e Ensino Superior in the framework of the project "Institute for Research and Innovation in Health Sciences" (POCI-01-0145-FEDER-007274), and a grant from Portuguese Society of Nephrology.

Institutional Review Board Statement: This study was approved by the Ethics Committee for Health and the Local Institutional Review Board of São João University Hospital Centre (approval number CES 251.14) and was carried out in accordance with the Declaration of Helsinki (2008) of the World Medical Association.

Informed Consent Statement: Informed consent was obtained from all subjects involved in the study.

Data Availability Statement: The data presented in this study are available on request from the corresponding author.

Acknowledgments: This article is a result of the project NORTE-01-0145-FEDER-000012, supported by Norte Portugal Regional Operational Programme (NORTE 2020), under the Portugal 2020 Partnership Agreement, through the European Regional Development Fund (ERDF). We thank R RonconAlbuquerque for the kind assistance in revising the manuscript.

Conflicts of Interest: All the authors declare that there is no conflict of interest.

\section{References}

1. Barsoum, R.S. Chronic kidney disease in the developing world. N. Engl. J. Med. 2006, 354, 997-999. [CrossRef] [PubMed]

2. Nugent, R.A.; Fathima, S.F.; Feigl, A.B.; Chyung, D. The burden of Chronic Kidney Disease on developing nations: A 21st century challenge in global health. Nephron Clin. Pract. 2011, 118, c269-c277. [CrossRef] [PubMed]

3. Manjunath, G.; Tighiouart, H.; Ibrahim, H.; MacLeod, B.; Salem, D.N.; Griffith, J.L.; Coresh, J.; Levey, A.S.; Sarnak, M.J. Level of kidney function as a risk factor for cardiovascular outcomes in the elderly. J. Am. Coll. Cardiol. 2003, 63, 1121-1129. [CrossRef]

4. Anavekar, N.S.; Pfeffer, M.A. Cardiovascular risk in chronic kidney disease. Kidney Int. 2004, 66, S11-S15. [CrossRef]

5. Go, A.S.; Chertow, G.M.; Fan, D.; McCulloch, C.E.; Hsu, C.Y. Chronic kidney disease and the risks of death, cardiovascular events, and hospitalization. N. Engl. J. Med. 2004, 351, 1296-1305. [CrossRef] [PubMed] 
6. Sarnak, M.J.; Levey, A.S.; Schoolwerth, A.C.; Coresh, J.; Culleton, B.; Hamm, L.L.; McCullough, P.A.; Kasiske, B.L.; Michael, E.K.; Klag, J.; et al. Wilson Kidney Disease as a Risk Factor for Development of Cardiovascular Disease. Circulation 2003, 108, 2154-2169. [CrossRef]

7. Irie, F.; Iso, H.; Sairenchi, T.; Fukasawa, N.; Yamagishi, K.; Ikehara, S.; Kanashiki, M.; Saito, Y.; Ota, H.; Nose, T. The relationships of proteinuria, serum creatinine, glomerular filtration rate with cardiovascular disease mortality in Japanese general population. Kidney Int. 2006, 69, 1264-1271. [CrossRef]

8. Tripepi, G.; Raso, F.M.; Sijbrands, E.; Seck, M.S.; Maas, R.; Boger, R.; Witteman, J.; Rapisarda, F.; Malatino, L.; Mallamaci, F.; et al. Inflammation and asymmetric dimethylarginine for predicting death and cardiovascular events in ESRD patients. Clin. J. Am. Soc. Nephrol. 2011, 6, 1714-1721. [CrossRef] [PubMed]

9. Gansevoort, R.T.; Correa-Rotter, R.; Hemmelgarn, B.R.; Jafar, T.H.; Heerspink, H.J.; Mann, J.F.; Matsushita, K.; Wen, C.P. Chronic kidney disease and cardiovascular risk: Epidemiology, mechanisms, and prevention. Lancet 2013, 382, 339-352. [CrossRef]

10. D’Elia, E.; Iacovoni, A.; Vaduganathan, M.; Lorini, F.L.; Perlini, S.; Senni, M. Neprilysin inhibition in heart failure: Mechanisms and substrates beyond modulating natriuretic peptides. Eur. J. Heart Fail. 2017, 19, 710-717. [CrossRef]

11. Unger, T.; Paulis, L.; Sica, D.A. Therapeutic perspectives in hypertension: Novel means for renin-angiotensin-aldosterone system modulation and emerging device-based approaches. Eur. Heart J. 2011, 32, 2739-2747. [CrossRef] [PubMed]

12. Xu, J.; Li, G.; Wang, P.; Velazquez, H.; Yao, X.; Li, Y.; Wu, Y.; Peixoto, A.; Crowley, S.; Desir, G.V. Renalase is a novel, soluble monoamine oxidase that regulates cardiac function and blood pressure. J. Clin. Investig. 2005, 115, 1275-1280. [CrossRef] [PubMed]

13. Hennebry, S.C.; Eikelis, N.; Socratous, F.; Desir, G.; Lambert, G.; Schlaich, M. Renalase, a novel soluble FAD-dependent protein, is synthesized in the brain and peripheral nerves. Mol. Psychiatry 2010, 15, 234-236. [CrossRef] [PubMed]

14. Maciorkowska, D.; Zbroch, E.; Malyszko, J. Circulating renalase, catecholamines, and vascular adhesion protein 1 in hypertensive patients. J. Am. Soc. Hypertens. 2015, 9, 855-864. [CrossRef]

15. Wang, F.; Li, J.; Xing, T.; Xie, Y.; Wang, N. Serum renalase is related to catecholamine levels and renal function. Clin. Exp. Nephrol. 2015, 19, 92-98. [CrossRef]

16. Wybraniec, M.T.; Wieczorek, J.; Woźniak-Skowerska, I.; Hoffmann, A.; Nowak, S.; Cichon, M.; Szydło, K.; Wnuk-Wojnar, A.; Chudek, J.; Więcek, A.; et al. Renalase is associated with adverse left atrial remodelling and disease burden in patients with atrial fibrillation undergoing pulmonary vein isolation. Kardiol. Pol. 2018, 76, 1232-1241. [CrossRef]

17. Lee, I.-T.; Sheu, W.H.-H. Serum Renalase Levels Are Predicted by Brain-Derived Neurotrophic Factor and Associated with Cardiovascular Events and Mortality after Percutaneous Coronary Intervention. J. Clin. Med. 2018, 7, 437. [CrossRef]

18. Baek, S.H.; Cha, R.H.; Kang, S.W.; Park, C.W.; Cha, D.R.; Kim, S.G.; Yoon, S.A.; Kim, S.; Han, S.Y.; Park, J.H.; et al. Circulating renalase predicts all-cause mortality and renal outcomes in patients with advanced chronic kidney disease. Korean J. Intern. Med. 2017. [CrossRef] [PubMed]

19. Malyszko, J.; Zbroch, E.; Malyszko, J.S.; Koc-Zorawska, E.; Mysliwiec, M. Renalase, a novel regulator of blood pressure, is predicted by kidney function in renal transplant recipients. Transplant. Proc. 2011, 43, 3004-3007. [CrossRef] [PubMed]

20. Quelhas-Santos, J.; Soares-Silva, I.; Fernandes-Cerqueira, C.; Simoes-Silva, L.; Ferreira, I.; Carvalho, C.; Coentrao, L.; Vaz, R.; Sampaio-Maia, B.; Pestana, M. Plasma and urine renalase levels and activity during the recovery of renal function in kidney transplant recipients. Exp. Biol. Med. 2014, 239, 502-508. [CrossRef]

21. Zbroch, E.; Malyszko, J.; Malyszko, J.; Koc-Zorawska, E.; Mysliwiec, M. Renalase in peritoneal dialysis patients is not related to blood pressure, but to dialysis vintage. Perit. Dial. Int. 2012, 32, 348-351. [CrossRef]

22. Zbroch, E.; Malyszko, J.; Malyszko, J.S.; Koc-Zorawska, E.; Mysliwiec, M. Renalase, a Novel Enzyme Involved in Blood Pressure Regulation, Is Related to Kidney Function but Not to Blood Pressure in Hemodialysis Patients. Kidney Blood Press. Res. 2012, 35 , 395-399. [CrossRef] [PubMed]

23. Gluba-Brzozka, A.; Michalska-Kasiczak, M.; Franczyk-Skora, B.; Nocun, M.; Banach, M.; Rysz, J. Markers of increased cardiovascular risk in patients with chronic kidney disease. Lipids Health Dis. 2014, 13, 135. [CrossRef]

24. Skrzypczyk, P.; Okarska-Napierala, M.; Stelmaszczyk-Emmel, A.; Gorska, E.; Panczyk-Tomaszewska, M. Renalase in children with chronic kidney disease. Biomarkers 2019, 24, 638-644. [CrossRef]

25. Wisniewska, M.; Serwin, N.; Dziedziejko, V.; Marchelek-Mysliwiec, M.; Dolegowska, B.; Domanski, L.; Ciechanowski, K.; Safranow, K.; Pawlik, A. Chronic kidney disease is associated with increased levels of renalase in serum and decreased in erythrocytes. Pol. Arch. Intern. Med. 2019, 129, 790-797. [CrossRef]

26. Serwin, N.M.; Wisniewska, M.; Cecerska-Heryc, E.; Safranow, K.; Skwirczynska, E.; Dolegowska, B. Serum-to-urine renalase ratio and renalase fractional excretion in healthy adults and chronic kidney disease patients. BMC Nephrol. 2020, 21, 77. [CrossRef] [PubMed]

27. Malyszko, J.; Koc-Zorawska, E.; Malyszko, J.S.; Kozminski, P.; Zbroch, E.; Mysliwiec, M. Renalase, stroke, and hypertension in hemodialyzed patients. Ren. Fail. 2012, 34, 727-731. [CrossRef]

28. Koc-Zorawska, E.; Malyszko, J.; Zbroch, E.; Malyszko, J.; Mysliwiec, M. Vascular adhesion protein-1 and renalase in regard to diabetes in hemodialysis patients. Arch. Med. Sci. 2012, 8, 1048-1052. [CrossRef]

29. Zbroch, E.; Koc-Zorawska, E.; Malyszko, J.; Malyszko, J.; Mysliwiec, M. Circulating levels of renalase, norepinephrine, and dopamine in dialysis patients. Ren. Fail. 2013, 35, 673-679. [CrossRef] [PubMed] 
30. Dziedzic, M.; Petkowicz, B.; Bednarek-Skublewska, A.; Solski, J.; Buczaj, A.; Choina, P. Relationship between renalase and N-terminal pro-B-type natriuretic peptide (NT pro-BNP) in haemodialysis patients. Ann. Agric. Environ. Med. 2014, $21,132-135$. [PubMed]

31. Oguz, E.G.; Gursoy, G.K.; Yayar, O.; Yildirim, T.; Cimen, T.; Bulut, C.; Eser, B.; Canbakan, B.; Yeter, E.; Ayli, M.D. Increased serum renalase in hemodialysis patients: Is it related to left ventricular hypertrophy? Ren. Fail. 2016, 38, 1180-1186. [CrossRef] [PubMed]

32. Gok Oguz, E.; Akoglu, H.; Ulusal Okyay, G.; Karaveli Gursoy, G.; Yildirim, T.; Merhametsiz, O.; Cimen, T.; Canbakan, B.; Yeter, E.; Ayli, M.D. Increased serum renalase in peritoneal dialysis patients: Is it related to cardiovascular disease risk? Nefrologia 2017, 37, 189-194. [CrossRef] [PubMed]

33. Wisniewska, M.; Serwin, N.; Dziedziejko, V.; Marchelek-Mysliwiec, M.; Dolegowska, B.; Domanski, L.; Ciechanowski, K.; Safranow, K.; Pawlik, A. Renalase in Haemodialysis Patients with Chronic Kidney Disease. J. Clin. Med. 2021, 10, 680. [CrossRef] [PubMed]

34. Zbroch, E.; Malyszko, J.; Malyszko, J.; Koc-Zorawska, E.; Mysliwiec, M. Renalase, kidney function, and markers of endothelial dysfunction in renal transplant recipients. Pol. Arch. Med. Wewn 2012, 122, 40-44. [CrossRef] [PubMed]

35. Stojanovic, D.; Cvetkovic, T.; Stojanovic, M.; Bojanic, V.; Stefanovic, N.; Stojanovic, I. The assessment of renalase: Searching for the best predictor of early renal dysfunction by multivariate modeling in stable renal transplant recipients. Ann. Transplant. 2015, 20, 186-192. [CrossRef] [PubMed]

36. Stojanovic, D.; Cvetkovic, T.; Stojanovic, M.; Stefanovic, N.; Velickovic-Radovanovic, R.; Zivkovic, N. Renalase Assessment With Regard to Kidney Function, Lipid Disturbances, and Endothelial Dysfunction Parameters in Stable Renal Transplant Recipients. Prog. Transplant. 2017, 27, 125-130. [CrossRef] [PubMed] 